\title{
Hematological profile of beef cattle with divergent residual feed intake, following feed deprivation
}

\author{
Rodrigo da Costa Gomes(1), Renata Farinelli de Siqueira(1), Michael Alan Ballou ${ }^{(2)}$, \\ Tiago Roberto Stella ${ }^{(1)}$ and Paulo Roberto Leme ${ }^{(1)}$
}

\begin{abstract}
(1)Universidade de São Paulo, Faculdade de Zootecnia e Engenharia de Alimentos, Avenida Duque de Caxias Norte, № 225, CEP 13635-900 Pirassununga, SP, Brazil. E-mail: gomes rc@hotmail.com, refarinelli@yahoo.com.br, tigostella@hotmail.com, prleme@usp.br (2)Texas Tech University, Department of Animal and Food Sciences, Box 42141, Lubbock, TX 79409, USA. E-mail: michael.ballou@ttu.edu
\end{abstract}

\begin{abstract}
The objective of this work was to characterize the hematological profiles of steers and bulls, according to residual feed intake (RFI), after feed deprivation. Twenty-month-old Nellore steers and bulls were fed feedlot diets for 70 and 56 days, respectively. RFI was calculated as the difference between actual feed intake and expected feed intake. More and less efficient steers and bulls, according to RFI, were subjected to 24 hours of food deprivation. Blood was sampled prior to and following the withdrawal period. Hematological analyses included total and differential white blood cell count, red blood cell count and morphology, and plasma glucose concentration. Variation in RFI did not influence plasma glucose concentration or blood cell profiles. Glucose concentrations in bulls decreased from 114 to $97 \mathrm{mg} \mathrm{dL}^{-1}$, but remained unchanged in steers, and the neutrophil:lymphocyte ratio increased from 0.39 to 0.57 following deprivation. Hematological profiles do not differ between more and less efficient steers and bulls, according to RFI.
\end{abstract}

Index terms: Bos indicus, fasting, feed efficiency, leukocytes, stress.

\section{Perfil hematológico de bovinos de corte com consumo alimentar residual divergente, após privação de alimentos}

\begin{abstract}
Resumo - O objetivo deste trabalho foi caracterizar os perfis hematológicos de novilhos e touros, de acordo com o consumo alimentar residual (CAR), após jejum de alimentos. Novilhos e touros Nelore, com 20 meses de idade, foram alimentados em confinamento por 70 e 56 dias, respectivamente. O CAR foi calculado como a diferença entre o consumo observado e o consumo esperado de alimentos. Novilhos e touros mais e menos eficientes, de acordo com o CAR, foram submetidos a jejum de alimentos por 24 horas. Amostras de sangue foram colhidas antes e após este período. As análises hematológicas incluíram contagem global e diferenciação de células brancas, contagem global e morfologia de células vermelhas, e concentração de glicose plasmática. A variação em CAR não influenciou a glicose plasmática ou o perfil de células sanguíneas. A concentração de glicose em touros diminuiu de 114 para $97 \mathrm{mg} \mathrm{dL}^{-1}$, mas manteve-se inalterada em novilhos, e a razão neutrófilo:linfócito aumentou de 0,39 para 0,57 após o jejum. Não foram observadas diferenças no perfil hematológico de novilhos e touros mais e menos eficientes, de acordo com o CAR.
\end{abstract}

Termos para indexação: Bos indicus, jejum, eficiência alimentar, leucócitos, estresse.

\section{Introduction}

Feeding costs represent one of the larger inputs of most beef enterprises (Arthur et al., 2004). Therefore, improving feed efficiency can dramatically increase profit in the meat industry (Cruz et al., 2010) and, moreover, mitigate the release of greenhouse gases and manure production, diminishing the environmental impact of the production of $1 \mathrm{~kg}$ of beef (Nkrumah et al., 2006; Hegarty et al., 2007).
Residual feed intake is a feed efficiency trait conceptually independent of growth rate and mature weight (Koch et al., 1963). Since selection for low residual feed intake decreases feed intake without compromising mature weight and the performance of the cow herd (Arthur et al., 2005; Basarab et al., 2007), this trait has been preferred to explain feed efficiency and to select the most efficient beef cattle.

Many studies have been carried out to evaluate the biological basis of variation for residual feed intake. 
Among the biological processes that affect feed efficiency, body heat production, stress, and tissue metabolism may account for part of the variation in this trait (Richardson \& Herd, 2004). In agreement, Australian studies have reported differences in the hematological profile of least and most efficient steers (Richardson et al., 1996, 2002), which could indicate variation in the demand for oxygen transport and stress susceptibility.

Changes in the hematological profile occur following exposure to stressors in mammals. Several studies have shown that plasma glucose levels, red blood cell parameters and white blood cell population can be altered during transportation (Earley et al., 2006; Canaes et al., 2009), weaning (Bueno et al., 2003), and food deprivation (Galyean et al., 1981; Chelikani et al., 2004). Since differences in growth performance and feed efficiency may be caused by resistance and resilience to stress, hematological profiles are likely to differ between high and low efficiency cattle following exposure to a stressor.

The objective of this work was to characterize the hematological profiles of steers and bulls according to residual feed intake, after feed deprivation.

\section{Materials and Methods}

The experiment was carried out at the Faculdade de Zootecnia e Engenharia de Alimentos of the Universidade de São Paulo, at Pirassununga, SP, Brazil (21 ${ }^{\circ} 57^{\prime} \mathrm{S}, 47^{\circ} 27^{\prime} \mathrm{W}, 605 \mathrm{~m}$ altitude). Cattle were first evaluated in two separate feeding trials to determine feedlot performance, including assessment of individual residual feed intake. Then, test animals were chosen and evaluated regarding hematological profiles.

In feeding trial 1, 72 steers were housed in individual pens and in drylots with Calan Broadbent feeding doors (American Calan Inc., Northwood, NH, USA). Individual pens were approximately $5 \times 8 \mathrm{~m}$ and received 36 animals. The other 36 steers were allotted to one of three group pens $(10 \times 23 \mathrm{~m})$ with Calan gates. Steers were 20 months old, with a mean body weight of $313 \mathrm{~kg}$, and were fed ad libitum a total mixed ration, with estimated metabolizable energy and crude protein content of $2.69 \mathrm{Mcal}$ and $14.3 \%$, respectively, on a dry matter basis (Table 1). An adjustment period of 21 days was allowed so that cattle learned how to feed from the
Calan system. After adaptation, dry matter intake was measured daily for 70 days, and cattle were weighed every 21 days, following an 18-hour feed withdrawal. Feed intake was obtained by weighing feed refusals daily. Average daily gain was calculated as the slope of the linear regression of body weight on feeding days.

In feeding trial 2, 48 bulls (413 $\mathrm{kg}$ of initial body weight, and 20 months of age) from a local producer (Fazenda Mundo Novo, Uberaba, MG, Brazil) were assigned to one of four group pens with Calan gates. Bulls were adapted to the individual feeding system over a 30-day period, and daily dry matter intake was measured over the subsequent 56-day period. During this period, animals were fed twice daily a corn silage-based diet $(2.40 \mathrm{Mcal}$ of metabolizable energy $\mathrm{kg}^{-1}$ of dry matter, $12.9 \%$ of crude protein, Table 1), and body weight was obtained every 21 days, after 18-hour fasting. Dry matter intake and average daily gain were measured as in trial 1 . For both steers and bulls, a total mixed ration was offered in order to allow 5 to $10 \%$ refusals.

Residual feed intake was calculated within trials, regressing dry matter intake against the mid-test metabolic body weight and average daily

Table 1. Ingredients and chemical composition of the experimental diets.

\begin{tabular}{|c|c|c|}
\hline \multirow[t]{2}{*}{ Ingredient } & \multicolumn{2}{|c|}{ Dry matter $\left(\mathrm{g} \mathrm{kg}^{-1}\right)$} \\
\hline & Trial 1 & Trial 2 \\
\hline Corn silage & - & 700 \\
\hline Coast-cross hay & 254 & - \\
\hline Citrus pulp & - & 68.8 \\
\hline Ground corn & 358 & 131 \\
\hline Soybean hulls & 350 & - \\
\hline Soybean meal ( $45 \%$ crude protein) & 22 & 88 \\
\hline Mineral premix ${ }^{(1)}$ & 6 & 6 \\
\hline Urea & 10 & 6 \\
\hline \multicolumn{3}{|l|}{ Nutrients } \\
\hline Dry matter & 732 & 414 \\
\hline Ether extract & 23 & 31 \\
\hline Neutral detergent fiber & 448 & 408 \\
\hline Acid detergent fiber & 301 & 258 \\
\hline Crude protein & 143 & 135 \\
\hline Metabolizable energy $(\text { Mcal kg-1) })^{(2)}$ & 2.69 & 2.40 \\
\hline
\end{tabular}

(1)Minimum content per kilogram of mineral premix in trial 1: $120 \mathrm{~g}$ of Ca, $18 \mathrm{mg}$ of $\mathrm{Co}, 15 \mathrm{~g}$ of P, $12 \mathrm{~g}$ of $\mathrm{Mg}, 400 \mathrm{mg}$ of Fe, $22 \mathrm{~g}$ of S, $297 \mathrm{mg}$ of $\mathrm{Cu}, 846 \mathrm{mg}$ of Mn, $2.5 \mathrm{mg}$ of Cr, $5 \mathrm{mg}$ of Se, 1,100 mg of Zn, $22 \mathrm{mg}$ of I, 110,000 UI Vit. A, 15,000 UI Vit. D, 100 UI, 1,000 mg of sodium monensin. Minimum content per kilogram of mineral premix in trial 2: $147 \mathrm{~g}$ of Ca, $80 \mathrm{mg}$ of $\mathrm{Co}, 60 \mathrm{~g}$ of P, $80 \mathrm{~g}$ of $\mathrm{Mg}, 12 \mathrm{~g}$ of S, $900 \mathrm{mg}$ of $\mathrm{Cu}, 800 \mathrm{mg}$ of $\mathrm{Mn}, 12 \mathrm{mg}$ of Se, $3,000 \mathrm{mg}$ of $\mathrm{Zn}, 120 \mathrm{mg}$ of I. ${ }^{(2)}$ Estimated according to the National Research Council (1996). 
gain, as follows: dry matter intake ( $\mathrm{kg}$ per day) $=\beta 0+\left(\beta 1 \times\right.$ body weight $\left.{ }^{0.75}\right)+(\beta 2 \times$ average daily gain) $+\varepsilon$, in which: $\beta 0$ is the intercept, $\beta 1$ is the linear coefficient related to body weight ${ }^{0.75}, \beta 2$ is the linear coefficient related to average daily gain, and $\varepsilon$ is the residual feed intake (actual dry matter intake minus the expected dry matter intake).

For steers (trial 1), the seven highest and seven lowest values according to residual feed intake were classified as high and low residual feed intake groups, respectively. For bulls (trial 2), high and low residual feed intake groups were formed by the ten highest and ten lowest residual feed intake values, respectively.

After the definition of the test groups (high and low residual feed intake cattle), animals were subjected to a stressor protocol based on feed deprivation for 24 hours. The day following the end of the feeding trial when residual feed intake was computed, the 48 bulls were allotted to two unsheltered large soil-surfaced drylots (30x40 m). After three days of adjustment, cattle were deprived of feed from $8 \mathrm{AM}$ to $8 \mathrm{AM}$ of the next day. For steers, animals classed as low or high residual feed intake cattle were removed from their original lot and put into individual pens (unsheltered, $5 \times 8 \mathrm{~m}$ ), where they continued to be fed ad libitum for 14 days. After this period, cattle were subjected to feed deprivation from $8 \mathrm{AM}$ to $8 \mathrm{AM}$ of the next day.

Blood was sampled 1 hour prior to and following the feed deprivation period. For that, cattle were walked gently $50 \mathrm{~m}$ until a squeeze chute where they were strained and blood was collected by venipuncture of the jugular vein, using vacuum tubes Vacutainer, containing heparin or $\mathrm{K}_{3}$-EDTA as additives (Becton Dickinson Ind. Cirúrgicas Ltda., Juiz de Fora, MG, Brazil). Heparinized blood was centrifuged $15 \mathrm{~min}$ after the withdrawal, at 2,000 rpm for $15 \mathrm{~min}$, and plasma was aliquoted in microtubes that were stored at $-20^{\circ} \mathrm{C}$ until analyses. EDTA blood was immediately taken to the laboratory for hematological analyses, including total and differential white and red blood cell count and morphology (Jain, 1986). The determination of hemoglobin was made by the colorimetric technique of potassium cyanide (Labtest, Lagoa Santa, MG, Brazil). Plasma glucose was determined using the enzymatic colorimetric kit CAT no 02200 , (Laborlab Ltda., Guarulhos, SP, Brazil).

Data were analyzed as repeated measurements by restricted maximum likelihood analysis of variance for a completely randomized design, using the Mixed procedure of SAS (SAS Institute, 2003). A linear, mixed model with the fixed effects of RFI class (low or high), feed deprivation (before and after), sex (steers and bulls) and all interactions was fitted. Least squares means $( \pm$ SEM) were reported throughout. Treatment effects were considered significant at $5 \%$ probability, and, when necessary, means were compared by the $\mathrm{t}$ test using the PDIFF option in Proc Mixed (SAS Institute, 2003).

\section{Results and Discussion}

No interactions between sex and residual feed intake class were observed for feedlot performance $(p>0.05)$ (Table 2). Bulls were significantly heavier than steers at the beginning and at the end of the feeding trial, as previously expected. Dry matter intake, both in kilograms and in percentage of body weight, was significantly lower for bulls than for steers. A possible explanation is that bulls received high forage diets, which may have limited feed intake through physical constraints. The limitation in feed intake may also have decreased growth rate in bulls, since the average daily gain of bulls and steers was similar, although lower growth rates were expected for steers. Bulls also had a significantly lower feed conversion ratio than steers, due to their enhanced lean growth. Since residual feed intake was calculated within trials, with an average of zero, no differences were observed between sex groups.

There were no differences between high and low residual feed intake cattle for initial and final

Table 2. Feedlot performance of Nellore steers and bulls with high and low residual feed intake (RFI).

\begin{tabular}{|c|c|c|c|c|c|c|c|c|}
\hline \multirow[t]{2}{*}{ Trait $^{(1)}$} & \multicolumn{2}{|c|}{ Sex } & \multicolumn{2}{|c|}{ RFI } & \multirow[t]{2}{*}{$\mathrm{SE}^{(2)}$} & \multicolumn{3}{|c|}{$\mathrm{F}$} \\
\hline & Steers & Bulls & High & Low & & Sex & RFI & $\begin{array}{c}\operatorname{Sex} x \\
\text { RFI }\end{array}$ \\
\hline$\overline{\mathrm{IBW}}(\mathrm{kg})$ & 339 & 417 & 381 & 375 & 7.96 & $*$ & ns & ns \\
\hline FBW (kg) & 451 & 488 & 472 & 467 & 5.43 & $* *$ & ns & ns \\
\hline DMI (kg per day) & 10.4 & 9.10 & 10.7 & 8.83 & 0.21 & $* *$ & $* *$ & ns \\
\hline DMI ( $\%$ of body weight $)$ & 2.62 & 2.01 & 2.52 & 2.12 & 0.06 & $* *$ & $* *$ & ns \\
\hline ADG (kg per day) & 1.56 & 1.65 & 1.59 & 1.61 & 0.03 & ns & ns & ns \\
\hline FCR $\left(\mathrm{kg} \mathrm{kg}^{-1}\right)$ & 6.72 & 5.56 & 6.76 & 5.54 & 0.16 & $* *$ & $* *$ & ns \\
\hline RFI (kg per day) & 0.04 & 0.03 & 0.93 & -0.86 & 0.16 & ns & $* *$ & ns \\
\hline
\end{tabular}

Pesq. agropec. bras., Brasília, v.46, n.9, p.1105-1111, set. 2011 
body weight and average daily gain. Cattle with low residual feed intake showed significantly lower dry matter intake, feed conversion ratio and residual feed intake than animals with high residual feed intake. These results are consistent with the residual feed intake concept of being independent of growth rate and body weight (Koch et al., 1963), agreeing with previous studies on Bos taurus breeds (Arthur et al., 2001a, 2001b). Low residual feed intake cattle ate less, had a better feed conversion ratio and had the same body weight and growth rate as the high RFI cattle; therefore, low residual feed intake cattle are considered more efficient. According to these results, residual feed intake can be used to explain feed efficiency in Nellore cattle.

No effects of sex, stress, and sex x stress interactions were observed $(p>0.05)$ for red blood cell count, hematocrit, hemoglobin, mean corpuscular volume, mean corpuscular hemoglobin, and mean corpuscular hemoglobin concentration. Lymphocytes and neutrophils were the most frequent leukocyte types, accounting for $88 \%$ of white blood cells, in agreement with other studies (Richardson et al., 2002, 2004; Amorim et al., 2003).

No effects of sex, stress, and sex $\mathrm{x}$ stress interactions were observed for white blood cell count $(p>0.05)$. However, interactions were significant for neutrophil percentage, lymphocyte percentage, neutrophil:lymphocyte ratio, and plasma glucose $(p<0.05)$. None of the white blood cell parameters were altered when steers were subjected to 24 hours of feed deprivation (Figure 1). After feed deprivation, bulls had increased neutrophil count (32\%) and neutrophil:lymphocyte ratio (46\%), and decreased lymphocyte count $(10 \%)$. Steers had higher glucose levels than bulls (123 and $106 \mathrm{mg} \mathrm{dL}^{-1}$, respectively), while glucose concentrations in bulls decreased from 114 to $97 \mathrm{mg} \mathrm{dL}^{-1}$ following feed deprivation, but remained unchanged in steers (Figure 2).

These results indicate that a 24-hour feed deprivation was a stressor for bulls only. Pires et al. (2007) found that a 24-hour fasting period altered white blood cell population and red blood cell parameters, and decreased plasma glucose in broilers, but did not report differences between sex groups (female and male). Small decreases in plasma glucose were observed in lactating cows after 8-hour fasting (Chelikani et al., 2004 ) and in steers after 18 or 32 hours of deprivation
(Galyean et al., 1981). Conversely, Earley et al. (2006) reported that an 8-hour food fasting period did not alter plasma glucose, mean corpuscular hemoglobin concentration, white blood cell numbers, lymphocyte percentage, red blood cell count, and hematocrit in young bulls.

According to Galyean et al. (1981), although plasma glucose was depressed in fasting cattle, hyperglycemia was observed in steers subjected to deprivation and transport concomitantly, indicating that fasting itself causes a lower degree of stress in comparison to transport. This observation is in agreement with studies regarding the effects of transportation on the physiological status of young bulls (Earley et al., 2006) and Alpine goats (Canaes et al., 2009) and the effects of weaning in blood parameters of heifers (Bueno et al., 2003), which indicate that stress causes hyperglycemia. Therefore, in the present study, feed deprivation should be considered a mild stressor, since it did not result in hyperglycemia, even though the neutrophils:lymphocytes ratio had been increased. The decrease in plasma glucose caused by feed deprivation was probably due to a reduction in the production of gluconeogenic short-chain fatty acids in the rumen, as a consequence of the smaller pool of substrates for rumen microorganisms (Galyean et al., 1981).

No significant residual feed intake class $\mathrm{x}$ sex, residual feed intake class $x$ fasting (before and after) and residual feed intake class $\mathrm{x}$ sex $\mathrm{x}$ stress interactions were observed for blood parameters

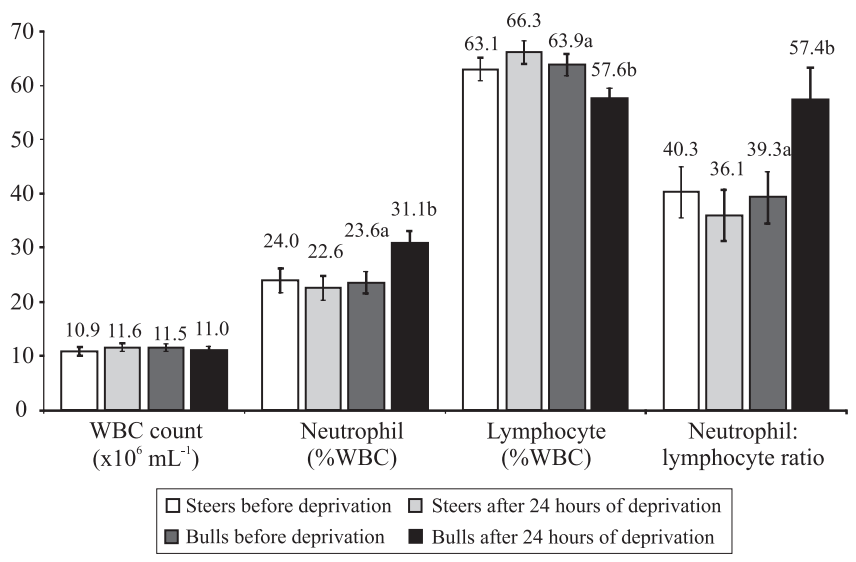

Figure 1. White blood cell (WBC) parameters of bulls and steers, before and following 24 hours of food deprivation. Means followed by the same letters do not differ by the $\mathrm{t}$ test, at $5 \%$ probability. 
( $p>0.05)$. Independently of sex group or fasting, there were no differences between most and least efficient Nellore cattle for plasma glucose, white blood cell count, lymphocyte percentage, monocyte percentage, eosinophil percentage, neutrophil percentage, red blood cells, hematocrit, hemoglobin, mean corpuscular volume, mean corpuscular hemoglobin and mean corpuscular hemoglobin concentration ( $p>0.05)$. Plasma glucose and blood parameters were similar to those found by Richardson et al. $(2002,2004)$ in Angus adult cattle, by Birgel Junior et al. (2001) in Jersey cows, and by Amorin et al. (2003) in Nellore heifers.

Few investigations have focused on the consequences of selection for diminishing feeding costs on immune-competence and stress susceptibility in beef cattle. In poultry, studies have shown that lines selected for growth experienced a significant decrease in immune function (Most et al., 2011). Therefore, there could be a trade-off between productive traits (including feed efficiency) and immune capacity. According to Richardson et al. (2002), high residual feed intake cattle (less efficient) had more neutrophils, less lymphocytes, and a lower white blood cell count than low residual feed intake steers (more efficient), exhibiting a typical hematological profile of mildly stressed cattle. Thus, there may be a negative association between feed efficiency, stress susceptibility and cellular immune-competence in beef cattle.

The data obtained in the present study partially agrees with Richardson et al. (2002), who reported no

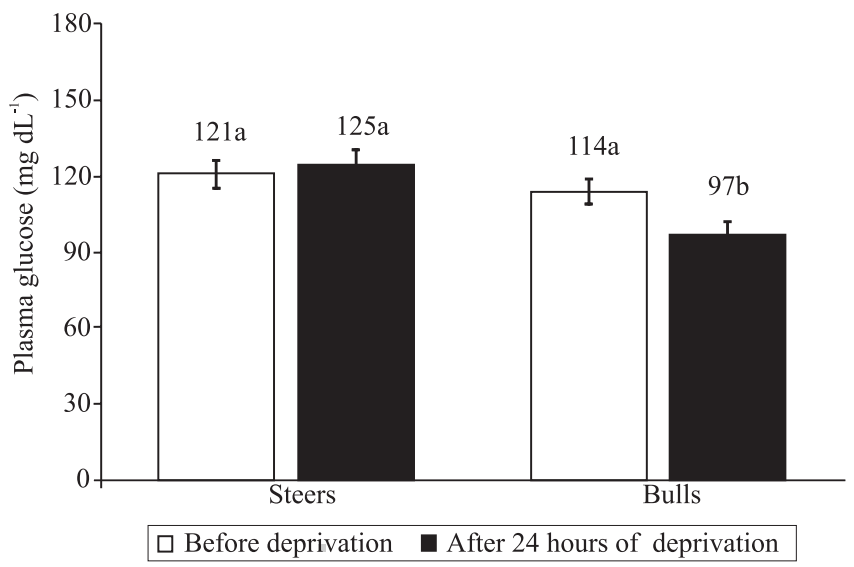

Figure 2. Plasma glucose of steers and bulls, before and following 24 hours of food deprivation. Means followed by the same letters, do not differ by the $\mathrm{t}$ test, at $5 \%$ probability. differences between high and low residual feed intake progenies of Angus (and crosses) steers, following a single generation of divergent selection for residual feed intake, for blood parameters. However, in the same study, the authors observed significant regression coefficients between sire expected breeding value (EBV) for residual feed intake and mean levels of white blood cell count, lymphocyte count, hemoglobin level and hematocrit. Additionally, Richardson et al. (1996) reported that high residual feed intake steers had a higher mean corpuscular volume and mean corpuscular hemoglobin in comparison to low residual feed intake cattle, indicating the existence of associations between residual feed intake and red blood parameters. However, these results were not supported by the present study.

The findings of Richardson et al. (2002) indicate an increase in the oxygen-carrying capacity of blood for the least efficient steers (high residual feed intake). An increased demand for oxygen transport agrees with a higher energy intake in high RFI steers, as well as with greater activity and heat production (Basarab et al., 2003; Nkrumah et al., 2006). In the present study, high residual feed intake cattle consumed more feed than low residual feed intake steers, which could increase oxygen consumption and demand a higher capacity of oxygen transportation in high residual feed intake animals. However, increasing oxygen consumption should not necessarily change red blood cell parameters, in order to enhance oxygen-carrying capacity. Heart rate can also be altered for this purpose, as indicated by the higher heart rate in heifers fed high energy diets when compared to heifers receiving low energy diets (Brosh et al., 1998). However, there are no known studies on the relationship between heart rate and feed efficiency.

\section{Conclusions}

1. There are no associations among residual feed intake, characteristics of white blood cell population and red blood cell parameters in Nellore cattle.

2. A short-term feed deprivation ( 24 hours) can be considered a mild stressor for Nellore bulls but not for steers.

3. Patterns of alterations in hematological profiles following a mild stressor do not differ between high (less efficient) and low (more efficient) residual feed intake Nellore cattle.

Pesq. agropec. bras., Brasília, v.46, n.9, p.1105-1111, set. 2011 


\section{Acknowledgments}

To Fundação de Amparo à Pesquisa do Estado de São Paulo, for financial support.

\section{References}

AMORIM, R.M.; BORGES, A.S.; KUCHEMBUK, M.R.G.; TAKAHIRA, R.K.; ALENCAR, N.X. Bioquímica sérica e hemograma de bovinos antes e após a técnica de biópsia hepática. Ciência Rural, v.33, p.519-523, 2003.

ARTHUR, P.F.; ARCHER, J.A.; HERD, R.M. Feed intake and efficiency in beef cattle: overview of recent Australian research and challenges for the future. Australian Journal of Experimental Agriculture, v.44, p.361-369, 2004.

ARTHUR, P.F.; ARCHER, J.A.; JOHNSTON, D.J.; HERD, R.M.; RICHARDSON, E.C.; PARNELL, P.F. Genetic and phenotypic variance and covariance components for feed intake, feed efficiency, and other postweaning traits in Angus cattle. Journal of Animal Science, v.79, p.2805-2811, 2001a.

ARTHUR, P.F.; HERD, R.M.; WILKINS, J.F.; ARCHER, J.A. Maternal productivity of Angus cows divergently selected for post-weaning residual feed intake. Australian Journal of Experimental Agriculture, v.45, p.985-993, 2005.

ARTHUR, P.F.; RENAND, G.; KRAUSS, D. Genetic and phenotypic relationships among different measures of growth and feed efficiency in young Charolais bulls. Livestock Production Science, v.68, p.131-139, 2001b.

BASARAB, J.A.; MCCARTNEY, D.; OKINE, E.K.; BARON, V.S. Relationships between progeny residual feed intake and dam productivity traits. Canadian Journal of Animal Science, v.87, p.489-502, 2007.

BASARAB, J.A.; PRICE, M.A.; AALHUS, J.L.; OKINE, E.K.; SNELLING, W.M.; LYLE, K.L. Residual feed intake and body composition in young growing cattle. Canadian Journal of Animal Science, v.83, p.189-204, 2003.

BIRGEL JUNIOR, E.H.; D'ANGELINO, J.L.; BENESI, F.J.; BIRGEL, E.H. Valores de referência de leucograma de bovinos da raça Jersey criados no Estado de São Paulo. Brazilian Journal of Veterinary Research and Animal Science, v.38, p.136-141, 2001.

BROSH, A.; AHARONI, Y.; DEGEN, A.A.; WRIGHT, D.; YOUNG, B. Estimation of energy expenditure from heart rate measurements in cattle maintained under different conditions. Journal of Animal Science, v.76, 3054-3064, 1998.

BUENO, A.R.; RASBY, R.; CLEMENS, E.T. Age at weaning and the endocrine response to stress. Arquivo Brasileiro de Medicina Veterinária e Zootecnia, v.55, p.1-7, 2003. http://dx.doi. org/10.1590/S0102-09352003000100001.

CANAES, T.S.; NEGRÃO, J.A.; PAIVA, F.A.; ZAROS, M.; DELGADO, T.F.G. Influência do transporte e mudança de local de manejo nas variáveis fisiológicas e produtivas de cabras Alpinas. Arquivo Brasileiro de Medicina Veterinária e Zootecnia, v.61, p.935-940, 2009.
CHELIKANI, P.K.; AMBROSE, J.D.; KEISLER, D.H.; KENNELLY, J.J. Effect of short-term fasting on plasma concentrations of leptin and other hormones and metabolites in dairy cattle. Domestic Animal Endocrinology, v.26, p.33-48, 2004.

CRUZ, G.D.; RODRÍGUEZ-SÁNCHEZ, J.A.; OLTJEN, J.W.; SAINZ, R.D. Performance, residual feed intake, digestibility, carcass traits, and profitability of Angus-Hereford steers housed in individual or group pens. Journal of Animal Science, v.88, p.324-329, 2010.

EARLEY, B.; FISHER, A.D.; O'RIORDAN, E.G. Effects of pre-transport fasting on the physiological responses of young cattle to 8-hour road transport. Irish Journal of Agriculture and Food Research, v.45, p.51-60, 2006.

GALYEAN, M.L.; LEE, R.W.; HUBBERT, M.E. Influence of fasting and transit on ruminal and blood metabolites in beef steers. Journal of Animal Science, v.53, p.7-18, 1981.

HEGARTY, R.S.; GOOPY, J.P.; HERD, R.M.; MCCORKELL, B. Cattle selected for lower residual feed intake have reduced daily methane production. Journal of Animal Science, v.85, p.1479-1486, 2007.

JAIN, N.C. Schalm's veterinary hematology. $4^{\text {th }}$ ed. Philadelphia: Lea \& Febiger, 1986. 1221p.

KOCH, R.M.; SWIGER, L.A.; CHAMBERS, D.; GREGORY, K.E. Efficiency of feed use in beef cattle. Journal of Animal Science, v.22, p.486-494, 1963.

MOST, P.J. van der; JONG, B. de; PARMENTIER, H.K.; VERHULST, S. Trade-off between growth and immune function: a meta-analysis of selection experiments. Functional Ecology, v.25, p.74-80, 2011.

NATIONAL RESEARCH COUNCIL. Nutrient requirements of beef cattle. $7^{\text {th }}$ ed. Washington: National Academy Press, 1996. $242 \mathrm{p}$.

NKRUMAH, J.D.; OKINE, E.K.; MATHISON, G.W.; SCHMID, K.; LI, C.; BASARAB, J. A.; PRICE, M.A.; WANG, Z.; MOORE, S.S. Relationships of feedlot feed efficiency, performance, and feeding behavior with metabolic rate, methane production, and energy partitioning in beef cattle. Journal of Animal Science, v.84, p.145-153, 2006.

PIRES, D.L.; MALHEIROS, E.B.; BOLELI, I.C. Influence of sex, age, and fasting on blood parameters and body, bursa, spleen and yolk sac weights of broiler chicks. Brazilian Journal of Poultry Science, v.9, p.221-228, 2007.

RICHARDSON, E.C.; HERD, R.M. Biological basis for variation in residual feed intake in beef cattle. 2. Synthesis of results following divergent selection. Australian Journal of Experimental Agriculture, v.44, p.431-440, 2004.

RICHARDSON, E.C.; HERD, R.M.; ARCHER, J.A.; ARTHUR, P.F. Metabolic differences in Angus steers divergently selected for residual feed intake. Australian Journal of Experimental Agriculture, v.44, p.441-452, 2004.

RICHARDSON, E.C.; HERD, R.M.; ARTHUR, P.F.; WRIGHT, J.; XU, G.; DIBLEY, K.; ODDY, V.H. Possible physiological indicators 
for net feed conversion efficiency. Proceedings of the Australian Society of Animal Production, v.21, p.103-106, 1996.

RICHARDSON, E.C.; HERD, R.M.; COLDITZ, I.G.; ARCHER, J.A.; ARTHUR, P.F. Blood cells profiles of steer progeny from parents selected for and against residual feed intake. Australian Journal of Experimental Agriculture, v.42, p.901-908, 2002.

SAS INSTITUTE. SAS/STAT user's guide. Version 9.1. Cary: SAS Institute, 2003.

$\overline{\text { Received on June 15, } 2011 \text { and accepted on September 19, } 2011}$ 